Available online on 15.08.2019 at http://ajprd.com
(c) 2013-19, publisher and licensee AJPRD, This is an Open Access article which permits unrestricted non-
commercial use, provided the original work is properly cited

Open $\mathcal{O}_{\text {Access }}$

Case Report

\title{
Ayurvedic Management of Schizoaffective disorder - A case report
}

\section{Nima MP1 ${ }^{1}$, Jithesh $M^{2 *}$, Santosh $C^{3}$}

\author{
${ }^{1}$ MD Scholar, PG Department of Manasroga, V.P.S.V Ayurveda College,Kottakkal \\ ${ }^{2}$ Corresponding Author, Professor and Head, PG Department of Manasroga, V.P.S.V Ayurveda College \\ Kottakkal. \\ ${ }^{3}$ Medical Officer, Govt. Ayurveda Research Institute for Mental Diseases, Kottakkal
}

\begin{abstract}
A B S T R A C T
Schizoaffective disorder is a chronic mental health condition characterized by symptoms of Schizophrenia such as hallucinations and delusions, and symptoms of a mood disorder such as mania or depression. As it shares the symptoms of more than a single mental health condition, many affected with schizoaffective disorder are often erroneously diagnosed. The disorder is seen in about $0.3 \%$ of the population as per reported studies and both men and women are equally prone to the disease. But men often develop the illness at an earlier age than women. The modern management includes use of both mood stabilizers and antipsychotics. Ayurveda psychiatry categorizes the disorder under the category of unmada which is considered as the vibhrama or distorted function of eight factors including manas and buddhi. A 48 year old male patient attended the Psychiatric OPD two months back. He had decreased sleep, lack of interest in attending the job, self-talking etc. He also complained about hearing of voices in ear. According to the informant, he had reduced social mingling and increased suicidal thoughts and had several attempts for committing suicide. He has been suffering from these complaints since past 18 years. The case was diagnosed as Vatakaphaja Unmada considering the dosha predominance and a protocol with special preference to sodhana procedures were performed after admission. The selected protocol was observed to be effective in managing the condition. The case report stresses the role of Ayurveda treatment modalities in managing similar psychiatric conditions.
\end{abstract}

Keywords: Schizoaffective disorder, Bhutavidya, Unmada, PANSS scale, HAM-D scale

A R T I C L E I N F O: Received 15June 2019; Review Completed 20 July 2019; Accepted 30 July 2019; Available online 15 August 2019
Cite this article as:
Nima MP, Jithesh M*, Santosh C, Ayurvedic Management of Schizoaffective disorder - A case report, Asian Journal of
Pharmaceutical Research and Development. 2019; 7(4):56-59, DOI: http://dx.doi.org/10.22270/ajprd.v7i4.562
*Address for Correspondence:
Dr. Jithesh Madhavan, 2Corresponding Author, Professor and Head, PG Department of Manasroga, V.P.S.V Ayurveda College
Kottakkal

\section{INTRODUCTION}

$\mathrm{S}$ chizoaffective disorder is a psychiatric condition that includes symptoms of both that of Schizophrenia as well as a mood disorder. ${ }^{1}$ DSM 5 describes schizoaffective disorder as intermediate between Schizophrenia and a bipolar disorder. ${ }^{2}$ Schizoaffective disorder includes bipolar symptoms such as mania or depression as well as the symptoms of Schizophrenia including hallucinations and delusions. Thoughts may be affected and the person may find it hard to function familial, social and at the occupational level.
The cause of schizoaffective disorder is yet to be known for the medical community. Selected studies suggest that there may be a genetic component as the causative factor. ${ }^{3}$ The risk of a person increases if any first degree relative has Schizophrenia, bipolar disorder or any other mental health issues. Diagnosis will be based on patient's mental status examination and also the history of the condition contributed by the family members.

Before reaching a diagnosis, the medical professional must rule out other medical conditions such as alcohol or drug use disorders, thyroid dysfunction, temporal lobe epilepsy etc leading to similar presentations. ${ }^{4}$ The clinical manifestation 
of Schizoaffective disorders may fit in to these subtypes mixed type or either a maniac or depressive type. Diagnosis and management of schizoaffective disorders are really challenging. Treatment involves a combination of antipsychotics, antidepressants or mood stabilizers as per the demand from the condition. ${ }^{5}$

The Psychiatry in Ayurveda is deliberated under the main heading Bhutavidya or graha chikitsa which is one among the Ashtangas or eight specialty branches ${ }^{6}$ of Ayurveda. Ayurveda explains all these psychiatric anomalies under the umbrella term "Unmada". Unmada is considered to be the vibhrama or distortion of the manas, budhi, samjna etc which are eight in number and the pathology of almost all available psychiatric disorders are well explained under this heading. ${ }^{7}$

A diagnosed case of schizoaffective disorder was managed with an Ayurveda treatment protocol including rookshana, Snehapana, Virechana, nasya, etc.

\section{Presenting concerns}

A 48 year old male patient hailing from Calicut district of the northern part of Kerala attended our hospital OPD almost two months back. His prime concerns were of decreased sleep, lack of interest in going for job, self-talking etc. He also complained about hearing of voices in the ear. On interrogation with his wife, she presented that he had reduced social mingling and increased suicidal thoughts and done several attempts for committing suicide. He has been suffering from these complaints since past 18 years.

On detailed history, it was bring into being that the patient was of introvert nature from childhood itself. After completing his primary education, he started to work as a tailor. He had sexual relationship with several ladies. According to him, all were attracted towards him in one way or another. After his marriage also, he had an affair with a lady from his neighborhood. One day while he was playing with his sister's children, he felt that someone is slapping on his ear. He started running a long distance over from there. During that running, he lost his clothes. But he was not aware of it and continued running. As per him, some voices were heard in his ear which instructed him to run and commit suicide. He was admitted for 5 days in a nearby hospital and was on antipsychotic medication since then.

The subsequent episode occurred when his father died. There was increased wandering in the home and he tried to commit suicide by jumping in to sea. Similar episodes occurred when his father in law expired as well. When his wife was hospitalized for a kidney donation, yet again he showed certain psychotic features. He went out from hospital and travelled for hours in a train and tried to commit suicide by jumping out of the moving train. He returned home after a gap of one day. He says that sometimes he is a snake, sometimes a dog etc. These are all his rebirth or punarjanma, as per him. The voice which was heard in ear insisted him to commit suicide. He had a guilty feeling now days that he was still alive and had not committed suicide by now.

According to his wife, the patient had episodes of increased energy than usual. During that time, he was performing many jobs at a time without any rest such as cleaning aquarium, washing kennel etc. He had also episodes of decreased interest in usual activities. During that time, he was reluctant to do his tailoring job and return back the clothes given by the people for stitching. Thus he had episodes of increased energy and decreased energy in an almost alternative manner. He was not on any allopathic medication for the past 1 year of admission.

\section{Clinical findings}

General physical examination: - Pulse: 72 / min, Heart rate: 72/min, BP: 110/70 mm Hg, Respiratory rate: $18 / \mathrm{min}$, Weight: $69 \mathrm{~kg}$

\section{Mental status examination}

The patient was well built and good looking. Eye contact was maintained and rapport was established with ease. Considering the speech, intensity, pitch and speed was normal and also it was relevant as well, but there was decreased productivity. Mood was assessed to be euthymic but affect was mostly depressive in nature. Comprehension was intact and motor activity was normal. Regarding the domain perception, auditory hallucinations was dominant and it was commanding in nature in which an external voice was commanding him to commit suicide.

Stream and form of thought was not much goal oriented. There was no tangentiality or circumstantiality. Content of thought included the delusion of reference, grandiosity and control. He also said that he will be born as snake, cat etc. in every possible rebirth. He had a guilty feeling that he had killed the dog in his family by pouring kerosene when he was a little child. Attention and concentration was intact and he was well oriented to time, place and person. While considering the memory, his remote memory was slightly impaired. There was no impairment in the areas of abstract thinking, intelligence, judgment, reading and writing. On assessment, the Insight was graded as 5 .

\section{Ayurvedic clinical examination}

Dasavidha pareeksha or the ten fold clinical examination was performed and the following features were noted. Sareerika prakrti was VataPitta and manasa prakrti was tamasika. Main doshas involved in disease pathology were vata and kapha and there was a predominance of tamas. He belonged to janghala desa and kala was that of adana. He was a person with avara in satva and with madyama of vaya. His agni was vishama in nature. His abhyavaharana sakthi was pravara but jarana sakthi was madhyama. Srotas involved was manovaha srotas from the presenting features. Aggravating factors include usna kala, sleep distortion and akulatha or disturbance of the manas.

\section{Investigations and medications}

Blood and urine routine investigations were within normal limits. No investigations such as MRI - Brain were performed as the presentation was so chronic. He was ongoing antipsychotics -Risperidone and Ativan. But the intake was irregular and he was not on any medication since one year

\section{Diagnostic focus and assessment}


Considering the detailed history and mental status examination, the case was diagnosed as schizoaffective disorder with the current episode depression with psychotic features, as per ICD-10. It was included in F $25.2^{8}$ Schizoaffective disorder mixed type since the present case is having the symptoms of both depression and mania and current status is of depression. These are episodic disorders in which both affective and schizophrenic symptoms are prominent within the same episode of illness, preferably simultaneously, but at least within a few days of each other' ${ }^{9}$. Assessment was done using the Positive and Negative Syndrome Scale for Schizophrenia and Hamilton depression rating scale before and after the treatment package and also the quality of life was assessed using WHO - QOL - BREF scale. A good deal improvement was noted in the scores after the treatment.

\section{Therapeutic focus and assessment}

Table 1: Procedures with Rationale

\begin{tabular}{|c|c|c|c|}
\hline Procedure & No. of days & Medicine & Rationale \\
\hline Virecana & 1 & Avipattychurna $^{10}$ & Pitta samana \\
\hline Talapotichil & 7 & Puranadhatri and musta & $\begin{array}{l}\text { To induce sleep and to } \\
\text { make more liable }\end{array}$ \\
\hline Rookshana & 2 & Gandarvahastadikashaya - $60 \mathrm{ml}+$ Vaisvanarachoorna $-5 \mathrm{gm}$ & $\begin{array}{l}\text { To provide rookshana prior } \\
\text { to snehana }\end{array}$ \\
\hline Snehapana & 7 & Mahat Pancagavyaghrta $^{11}$ & $\begin{array}{l}\text { Vatha Kaphasamana, } \\
\text { unmadahara }\end{array}$ \\
\hline Abhyanga + Usmasveda & 3 & Danvantarataila $^{12}$ & Unmadahara \\
\hline \multicolumn{4}{|c|}{ Yogavasti } \\
\hline Snehavasti & 5 & Pancagavyaghrta + vacha $5 \mathrm{gm}+$ guduchi $-5 \mathrm{gm}^{13}$ & Unmadahara and medhya \\
\hline Kashayavasti & 3 & Yashti kwatha & VataPitta samana \\
\hline Nasya & 5 & Pancagavya ghrta $^{14}$ & Kapha samana, unmadahara \\
\hline
\end{tabular}

\section{DISCUSSION}

Mental diseases are dealt as a separate branch of Ayurveda called bhutavidya or graha chikitsa. The main diseases coming under this purview are unmada, apasmara, atatwabhinivesha etc. Unmada involves vibhrama of any of these factors - manas, buddhi, samjna, smrti, bakthi, seela, cheshta and achara. Viruddha ahara, vihara, avara satva, tamasika prakrti etc are considered to be the contributing factors in the manifestation of Unmada. ${ }^{15}$

The role of manas is being considered imperative in the pathogenesis of Unmada. It is already explained in the classics that the Vata dosha is the key controller of mind. ${ }^{16}$ So the treatment of Unmada should be planned considering the involvement of Vata dosha. Based on the symptomatology, the role of Pitta and Kapha should also be considered as associated dosha during the management

*The present case of Schizo-affective disorder can be explained under the condition of Vatakaphaja unmada. Considering the involvement of Pitta and for anulomana of Vatha, initially virecana was planned with 25 grams of Avipatty choorna for one day. After this, Sirolepa or Talapothichil was planned for 7 days with purana dhatri churna and musta so as to improve sleep and also to make the patient vulnerable for further management.

Sodhana procedures are quite essential in the treatment of unmada along with or ahead of the samana therapies. Before performing Snehapana, rookshana was planned so as to enhance the effect of snehana. ${ }^{17}$ For rookshana, Gandarvahastadi kwatha was given with 5 gram of
Vaisvanara choorna twice daily. After completing 2 days of rookshana, Snehapana was planned with Mahatpancagavya ghrta considering the Vatakaphahara nature of the drug. Drugs such as gomutra are capable of removing the avarana of the mind due to Kapha dosha as well.

After Snehapana at the doses $30 \mathrm{ml}, 60 \mathrm{ml}, 90 \mathrm{ml}, 120 \mathrm{ml}$, $160 \mathrm{ml}, 190 \mathrm{ml}$ and $220 \mathrm{ml}$ for 7 days, abhyanga and usmasveda was performed using Danvantara taila. Vamana was planned as the initial sodhana so as to get rid of the overindulged doshas. As the satva of the patient was avara and the subject was not ready for vamana, Virecana was done with Avipatty churna 30 gram in warm water. After providing rest for one day with dietary regulations, yogavasti module of nirooha was intended from the next day onwards.

Snehavasti was planned with Pancagavya ghrta added with 5 grams of vaca and guduci churna. Guduci was used considering the medya action as a rasayana. Vaca was added to augment the potency of Pancagavya ghrta and thus imparting a much more Kaphahara action due to tikshna nature. Kashayavasti was administered with yashti kashaya. After performing yogavasti, nasya was planned with Pancagavya ghrta at a dose of $1 \mathrm{ml}-2 \mathrm{ml}$ for 5 days. Patient felt more relaxed during the nasya procedure. The patient was discharged after the protocol with internal medication.

Internal medicine included somalatha choorna at a dose of 10 gram during night to ensure proper sleep. Also $10 \mathrm{gms}$ of mahapaisachika ghrta ${ }^{18}$ was administered during night which was having an action of improving buddhi and medha. A combination was also given which includes equal proportion of Swetasankupuspi, gokshura and sarpagandha at a dose 1 
gram twice daily after food with lukewarm water. Two manasamitra vataka $^{19}$ tablets were prescribed during night which can reduce the nature of anxiety and agitation.

Before and after the completion of treatment, patient was assessed with PANSS $^{20}$ assessment scale for Schizophrenia and Hamilton Depression rating scale $^{21}$ where much improvement was noted. HAM-D score reduced from 22 to 4. On assessing PANSS scale, positive scale showed changes from 32 to 9, Negative scale from 22 to 12 and General psycho-pathology scale from 57 to 28 before and after the therapy.

\section{CONCLUSION}

Schizoaffective disorder is one of the least explored areas in the field of psychiatry as per reported studies. The condition

\section{REFERENCES}

1. Ahuja N. A Short Textbook of Psychiatry. 7th ed. Jaypee Brothers medical publishers, (p) Ltd; 2011; p.87.

2. https://www.medicalnewstoday.com/articles/190678.php.

3. https://www.medicalnewstoday.com/articles/190678.php.

4. Benjamin JS, Virginia Alcott Sadock. Kaplan \& Sadock's Synopsis of Psychiatry-Behavioral Sciences/Clinical psychiatry.11th ed. Lippincott Williams \& Wilkins; 2007:324.

5. Ahuja N. A Short Textbook of Psychiatry. 7th ed. Jaypee Brothers medical publishers, (p) Ltd; 2011:87.

6. Bhișagācarya HV, Așțanga Hrdayam composed by Vāgbhața with commentaries of Arunadatta and Hemādri $.10^{\text {th }}$ ed. Varanasi: Choukhambha Orientalia; 2011:p.5.

7. Ācarya VYT, editor, Carakasaṃita by Agnives'a with the Āyurveda Dīpika Commentary. Varanasi: Chaukhamba Sanskrit Sansthan; 2017:223.

8. The ICD-10 Classification of mental and behavioural disorders. Delhi: World Health Organisation, AITBS Publishers.

9. Ahuja N. A Short Textbook of Psychiatry. 7th ed. Jaypee Brothers medical publishers, (p) Ltd; 2011; 87.

10. Bhișagācarya HV, editor. Așțanga Hrdayam composed by Vāgbhața with commentaries of Arunadatta and Hemādri $.10^{\text {th }}$ ed.Varanasi: Choukhambha Orientalia; 2011; 743.

20. WWW.Huibee.com $>2013 / 11>$ PANSS

21. Sharp R. The Hamilton Rating Scale for Depression. Occup Med Lond). 2015; 65:340. is often misdiagnosed in a primary clinic. The symptoms of the disease can be grouped under the eight vibhramas explained in the context of Unmada, in Ayurveda. Treatment should be planned considering the dosha predominance and usually varies from case to case. In the present case Kapha dosha is predominant with the association of other doshas. The condition was effectively managed with the selected protocol from the Ayurveda system of medicine even though, it cannot be generalized as such. Further vibrant research works have to be conducted and should be documented for the advancement of Ayurveda psychiatry and for the compassionate care of the affected.

11. Bhiṣagācarya HV, editor. AșțangaHrdayam composed by Vāgbhața with commentaries of Arunadatta and Hemādri $.10^{\text {th }}$ ed.Varanasi: Choukhambha Orientalia; 2011;803.

12. Bhișagācarya HV, editor. Așțanga Hraya composed by Vāgbhața with commentaries of Arunadatta and Hemādri .10 ${ }^{\text {th }}$ ed.Varanasi: Choukhambha Orientalia; $2011 ; 383$.

13. Bhiṣagācarya HY, editor. Așțanga Hrdaya composed by Vāgbhața with commentaries of Arunadatta and Hemādri .10 $0^{\text {th }}$ ed.Varanasi: Choukhambha Orientalia; 2011; 926.

14. Bhișagācarya HV, editor. AșțañgaHrdaya composed by Vāgbhaṭa with commentaries of Arunadatta and Hemādri .10 ${ }^{\text {th }}$ ed.Varanasi: Choukhambha Orientalia; 2011; 803.

15. Bhișagācarya HV, editor. AșțañgaHrdaya composed by Vāgbhața with commentaries of Arunadatta and Hemādri .10 ${ }^{\text {th }}$ ed.Varanasi: Choukhambha Orientalia; 2011; 797.

16. Ācarya VYT, editor, Carakasamphita by Agnives'a with the Āyurveda Dīpika Commentary. Varanasi: Chaukhamba Sanskrit Sansthan; 2017; p.79.

17. Bhișagācarya HY, editor. Așțañga Hrdaya composed by Vāgbhața with commentaries of Arunadatta and Hemādri .10 $10^{\text {th }}$ ed.Varanasi: Choukhambha Orientalia; 2011; 225.

18. Bhișagācarya HY, editor. AșțañgaHrdaya composed by Vāgbhața with commentaries of Arunadatta and Hemādri .10 ${ }^{\text {th }}$ ed.Varanasi: Choukhambha Orientalia; 2011; 799.

19. Sahasrayoga $31^{\text {st }}$ ed (KrishnanK.V, GopalapillaiS, comme, Malayalam) Alappuzha: Vidyarambham press; 2012. 